\title{
Designing Jumping Task on Percent using PMRI and Collaborative Learning
}

\author{
Ratu Ilma Indra Putri, Zulkardi \\ Universitas Sriwijaya, Jl. Srijaya Negara Kampus FKIP Unsri, Bukit Besar, Palembang, Indonesia \\ e-mail: zulkardi@unsri.ac.id
}

\begin{abstract}
Contrast to the shared task at the beginning of mathematics lesson, jumping task is the central part of the teaching that uses higher order thinking skills (HOTs) in Japan. In Indonesia, the curriculum 2013 revised stress on how to use HOTs in the mathematics lesson, the daily life context, and collaborative learning. The goal of this research to know the characteristics of the jumping task which valid, practical and useful supporting primary school students learning percents. This research uses design research as a method. In designing the content materials and their contexts, this research uses PMRI (Indonesian version of Realistic Mathematics Education instructional theory. Moreover, in the designing and implementing learning process, this research use lesson study for learning community (LSLC). Results of this research are valid and practical jumping tasks on mathematics topic percents. Students with low performance have difficulties in solving jumping tasks. However, with collaborative learning, students can answer the percent jumping tasks.
\end{abstract}

Keywords: Percent, Jumping Task, Collaborative Learning, PMRI, Design Research

How to Cite: Putri, R.I.I., \& Zulkardi. (2019). Designing jumping task on percent using PMRI and collaborative learning. International Journal on Emerging Mathematics Education, 3(1), 105-116. http://dx.doi.org/10.12928/ijeme.v3i1.12208

\section{INTRODUCTION}

People use percent in many jobs and activities in their daily life. Hence, the school mathematics curriculum consists of percent both in the primary and secondary school. However, many research shows that students learn percent only at the lowlevel order of student thinking not on the understanding and the application of percent.

Van den Hauvel-Panhuizen (1994) stated that students learn percent by practicing many problems using procedure and formula. Students do not know the meaning of the tasks due to the concept of mathematics is given to students at school directly at a formal level and presented as a separate concept from contextual problems (Van de Walle \& Folk, 2005; Parker \& Leinhardt, 1995).

The model bar can function at different levels of understanding (Van den Hauvel-Panhuizen, 2003). Furthermore, the use of bar models on percent learning is beneficial for students (Rianasari, Budaya, \& Patahuddin, 2012). The benefit of the first bar model is the bar model has an area that makes it easier to speak in "whole" terms (Van Galen, et al. 2008; Putri \& Zulkardi, 2017). With the bar, the model provides an excellent hold to estimating the percentage as a second benefit. Lastly, the third benefit is the bar model provides students with more opportunities to progress.

In PMRI teaching is built on informal knowledge of students. It is essential to give students the opportunity to explore some situations of everyday life where the percentage plays a role (Van den Hauvel-Panhuizen, 2003; Gunawan, Putri, \& Zulkardi, 2017; Putri \& Zulkardi, 2018; Nizar, Putri, \& Zulkardi, 2018; Indriasih, 2015). 
Consistently, learning can be systematically designed through Lesson Study activities. Learning Study based on Learning is a learning quality improvement approach originating from Japan. In Lesson Study activities a group of teachers collaboratively and continuously carry out, observe, and report learning outcomes. Lesson Study that builds Learning Community will make teachers more eager to improve the quality of teaching from within. This is what will later continue to strengthen their professionalism (Sato, 2014). With collaborative learning, the teacher can know the shortcomings and strengths of himself regarding teaching, so that the teacher will always want to improve himself to be better (Putri, 2018).

Currently, the 2013 curriculum suggests teachers guide students in learning mathematics to achieve the 21st-century skills or termed 4C (Communication, Collaboration, Critical Thinking, and Problem Solving, and Creativity and Innovation) (Putri \& Zulkardi, 2018; Putri, 2018). For this reason, to achieve 21st-century skills, it is necessary to improve the quality of learning by helping students to participate by emphasizing problem-based learning. One way that can be used through jumping tasks, which is given when learning takes place by using problems that can develop students' high-level thinking skills (Sato, 2014; Sato \& Sato, 2003). Also, jumping tasks can create learning activities among students such as dialogue, interaction and effective collaboration (Sato, 2014; Nofrion, 2012). Therefore, the purpose of this paper is to produce jumping tasks on topic percents which valid and practical in supporting primary school students at the fifth-grade learning HOTs mathematics in Palembang.

\section{RESEARCH METHOD}

This research used design research method with three phases (Gravemeijer \& Cobb, 2006; Putri \& Zulkardi, 2018). Firstly, the preliminary design phase which focuses on literature review, discussion with teacher model and designing prototype of Hypothetical Learning Trajectory (HLT). Participants of this research are teacher and students. Four mathematics teachers who teach the fifth-grade at MIN 2 Palembang were involved. The primary subject of this research is 35 of the fifth-grade students. In the design phase, the researchers and mathematics teachers compiled the lesson plans using bar models. In learning percent, the bar models were useful for students in understanding the concept. One of the benefits of using bar models is that they have an area that makes it easier to said "whole" terms (Van Galen, et al. 2008; Van Galen \& Van Eerde, 2013). The second benefits, bar models have the best estimating percent, especially in cases where the amount cannot only convert to a single fraction or percent. Then, the bar models give students more opportunities to make progress. It also means the bar models has functioned at a different level of understanding (Van den Heuvel Panhuizen, 2003), including alternative solution hypothesized by the teacher for pre-test on percent, validation, and prediction of pretest test solutions about percent. During the validation process of percent learning materials, all four mathematics teachers at MIN 2 Palembang were get involved.

In this activity, researchers and mathematics teachers on fifth-grade were designing the lesson plans, sharing the task, jumping task, and problems for the written test that adjusted to the principle and characteristics of PMRI. Also developed the learning percent using the learning community, discussed how learning should take place when students were doing the sharing task and jumping task. So the students can collaborate (learning community). After that, the student makes eight groups consisting four people (two females and two males, also the groups were

IJEME, Vol. 3, No. 1, March 2019, 105-116. 
heterogenous consists of smart, moderate, and low students, that were confirmed directly by mathematics teacher on fifth-grade) (Putri, 2018). Figure 1 shows a sharing task using parking lot context.

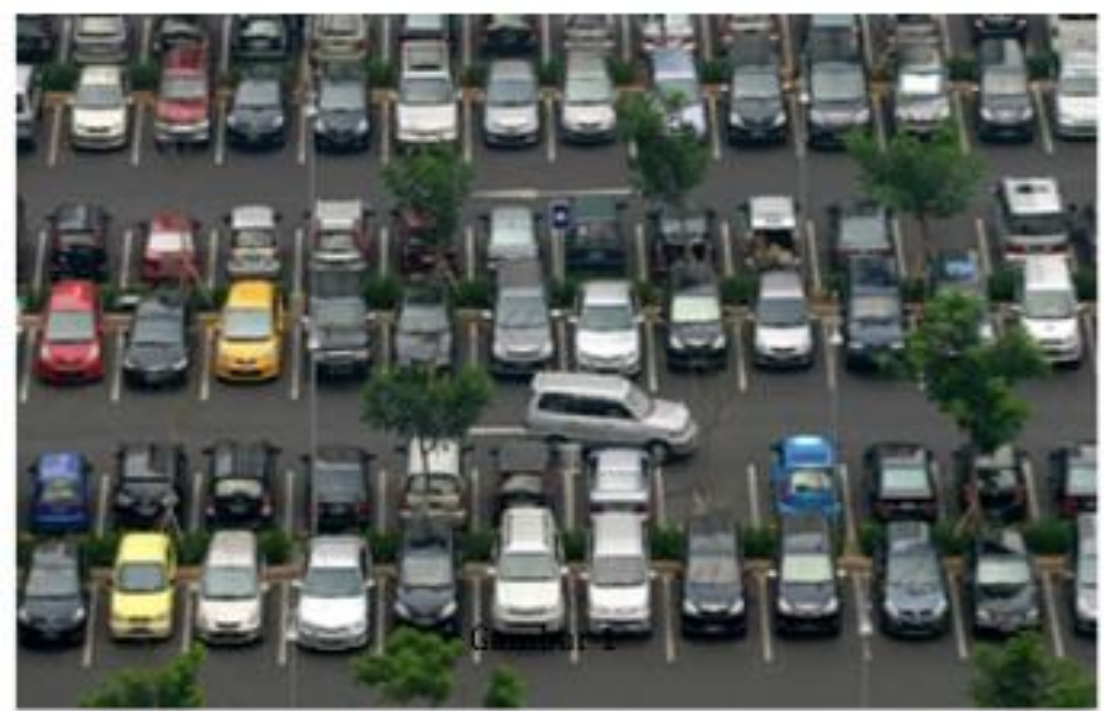

Figure 1. Parking Lot Context

During the design phase, the researcher in collaboration with the teachers produces three activities sharing tasks for students to help them understand the concept of percent. Also, they design the jumping task at the level analysis. Figure 2 shows the jumping tasks.
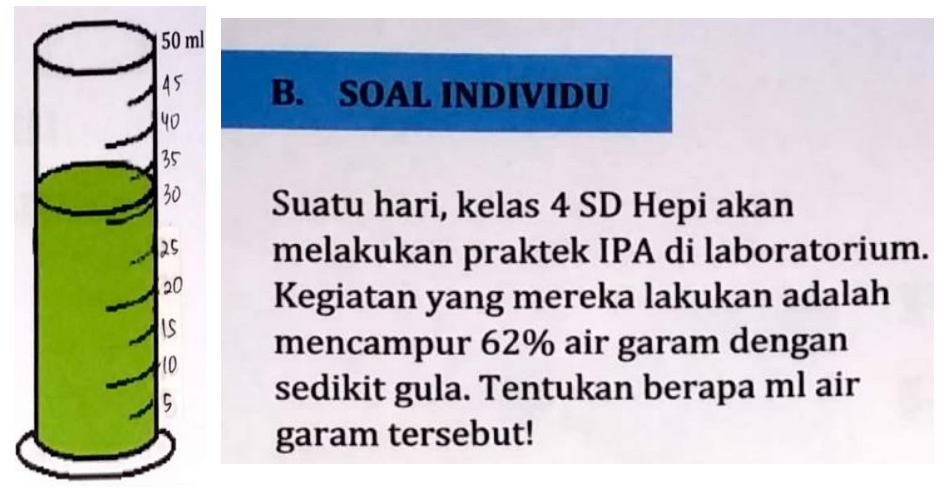

Figure 2. Jumping Task

HLT was designed for one meeting with two activities. The goal of the first activity is students can analyze percent from bar percentage. Then, the second goal students can analyze percent using the volume of water in the measurement glass. After finishing activities, the students solved some given problems. The instructional process was conducted using system LSLC and PMRI theory. Data in this research were collected via test, interview, and documentation such as student solutions, photos, and videos.

The experiment phase focuses on both the pilot experiment and teaching experiment. In the pilot experiment, the subject is six fifth-grade students at MIN 2 Palembang. During the experiment, the mathematics teacher performs as an observer, 
while an observer performs as a model teacher. Furthermore, the real teaching experiment was conducted at the real class with 35 fifth grade students of MIN2. During the experiment, the class is divided into nine groups with different abilities. In this implementation step, the researchers performed as an observer and collected the research data in the form of test on students' ability to understand a mathematical concept. Also, the researcher doing some interviews, taking video and photo that focused on students' expressions and thinking.

Finally, reflection on the implementation of the second cycle focuses on analysis that compares HLT (Hypothetical Learning Trajectory) with ALT (Actual Learning Trajectory). The observation and reflection phase aims to discover the strengths and weaknesses of the implementation of learning. The educators reflect the effectiveness of learning and mutual learning in collaborative. The activity begins with delivered the impression of knowledge, and then the observer gives a response. Criticism and suggestion geared to improve the quality of learning and offered wisely without degrading and hurting the lecturers. Positive feedback can be used to redesign better learning (Widiadi \& Utami, 2016).

\section{RESULTS AND DISCUSSION}

The implementation of the lesson starts with apperception (Figure 3). It began with a reminder of the worth of broken pieces, using two papers. The first paper was folded in half so that there were two parts. The second paper was doubled and doubled back so that there were four parts and each into one piece of 4 parts. Then compare the size of 1 part of the first paper with the size of 2 parts of the second paper. Next illustrates the shape of the paper size compared to the blackboard and directs the students that this means that the ratio of the paper is a fraction of value.

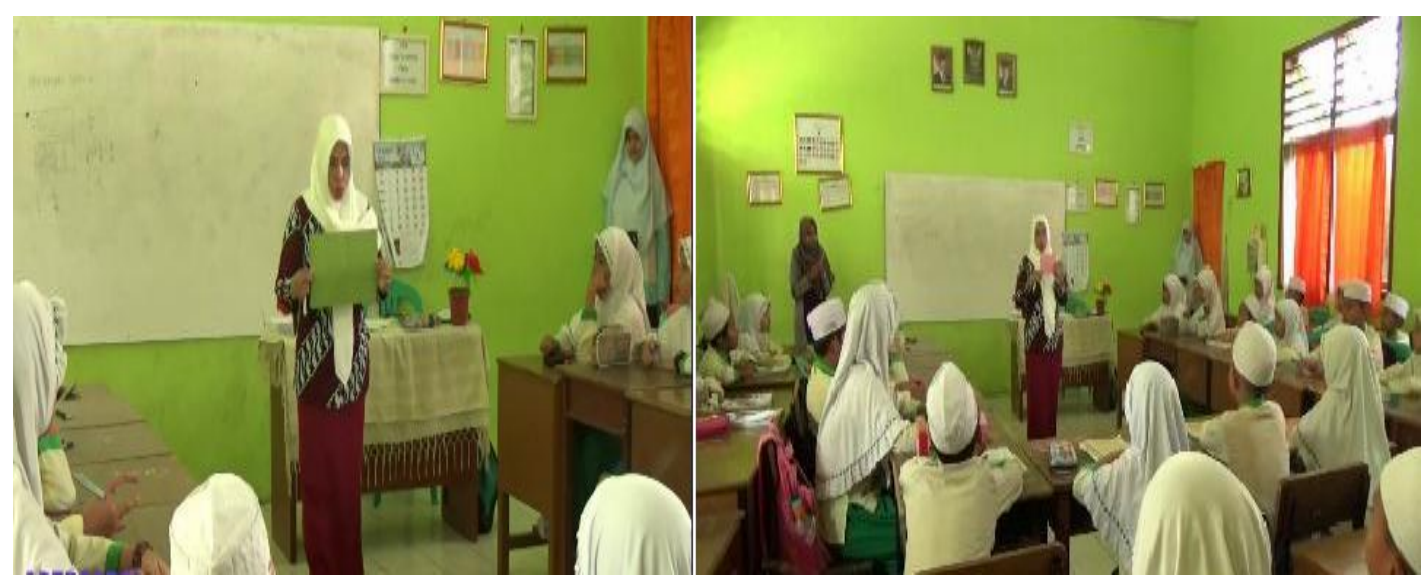

Figure 3. Teacher Apperception

Then the teacher reminds the learning system with the rules of the game. The student must say "Please Teach $\mathrm{Me}$ " to his friend if he does not understand, and students who are asked for help must teach it. Furthermore, the teacher asked for group students consisting of four. With 35 students, there are eight groups. Then teachers give the share tasks as the first activity and then the second activity which was a matter of jumping. The teacher instructs students to work in groups, where if there are students who do not understand, the student is asked to find help to friends with the rules of working in groups (Figure 4). 


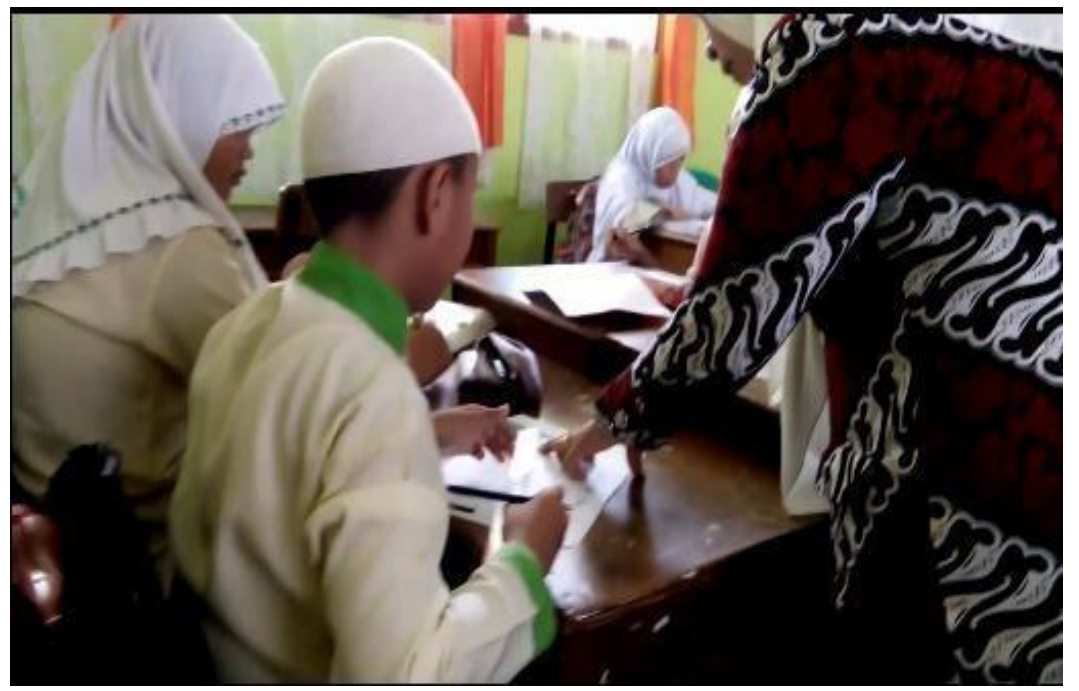

Figure 4. Teacher Monitors Student Activities

The teacher asks three students to present their answers orally in the middle of the class. After the student finished the presentation, the teacher shares individual questions (planned as jumping tasks) to each student and tells them to do it individually. For activity 2 , there is one group that is used as a focus for which one member does not understand working on problem number 1 and asks for help taught by students who already comprehend while other students continue their work (Figure 5).

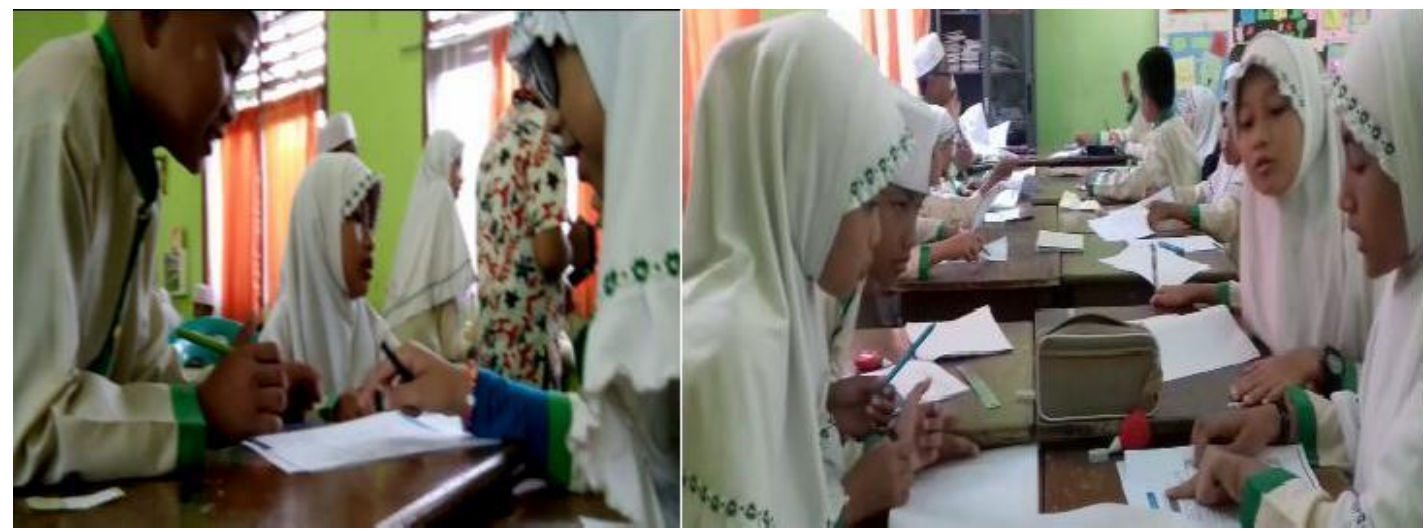

Figure 5. Several Working Groups

When students solve a jumping problem, students seem unable to solve the problem, so the teacher directs to ask for help from his friend. Here are the answers of the student representatives when solving jumping questions.

In this research, three activities were designed as references for teachers when teaching about percent. Every action gave explanations some activities or description of learning activity, the learning objectives, fundamental knowledge that students must have, conjecture of students' thinking, and the abilities that students got after the learning process. In the operation of the first cycle (pilot experiment) to the second cycle (teaching experiment) allows for revision on the learning activities. The iceberg of percent material is in Figure 6. 


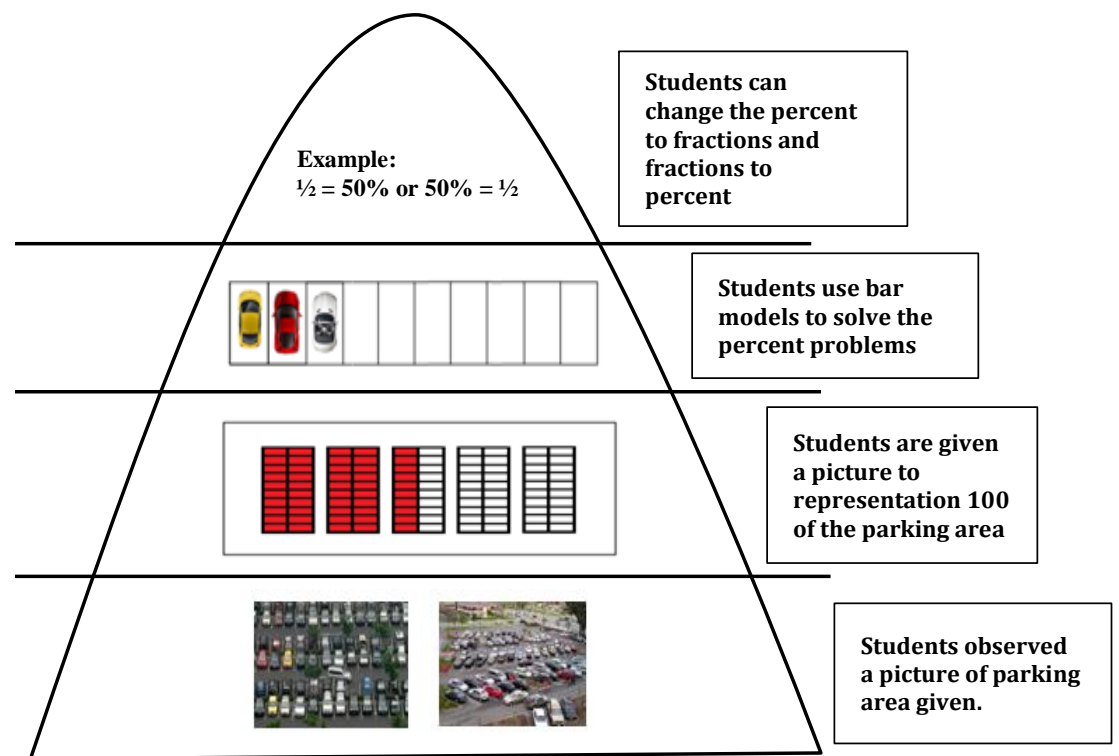

Figure 6. The Iceberg of Percent Material

In the teaching experiment phase, the teacher forms the students into several groups, and then students discuss in their group to solve the problems given on the student activities worksheet. Firstly, students working on the first activity in the group, and students asked to identify the first activity contained in the shared sheet within each group. In the first activity, the teacher connects the percent material with the picture of the parking area that exists on the activities sheet. Students are given several questions related to the parking area in conversation 1 , as follows $(S=$ all students, $\mathrm{G}=$ teacher):

G : "Okay if you already get the LAS, now let's look at the first page on your LAS, there's the first activity which starts with the picture. What is the picture about?"

S : "Cars."

G : "Yaa, precisely it's the area where cars or motorcycle are parked."

S : "Parking area?"

G : "Yes, you're right. So, have you ever seen it before?"

$\mathrm{S} \quad$ : "Of course, at the mall!"

G : "Other than that?"

S : "Airport."

G : "Good, at airport.... What else?"

S : "Hotel."

G : "Okay, now let's have a look at the second page. There're four questions, and you have to discuss it and answer the questions."

The second conversation from group 2, $(\mathrm{S} 1=$ first student in group $\mathrm{S} 2=$ second student in group, $\mathrm{S} 3$ = third student in group, $\mathrm{G}=$ teacher) as follows:

S1 : "Is there a parking area?"

S2 : "Yes, there is."

S1 : "Write down please."

S3 : "Tell us about the condition of your parking area at your school." 


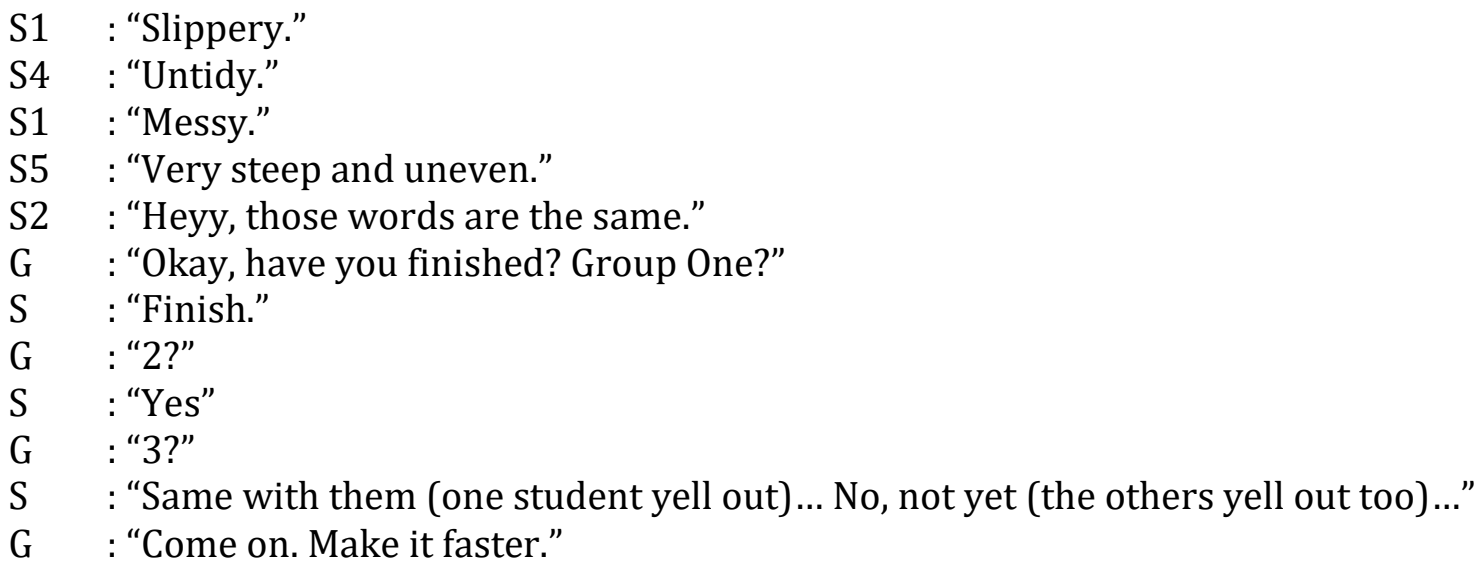

Based on the discussion between the teacher and students above, students showed that they already know about the parking area or students have been able to imagine what is the function of the parking area and the shape of the parking area. It shows that the context of the parking area is following the PMRI principles, that is didactical phenomenology. The social context of the parking area that using bar can be used as a starting point in learning percent, therefore it's one of the ways to formal knowledge, namely percent (Van Galen, et al. 2008; Putri \& Zulkardi, 2018).

In the next step, the teacher asked the students to do the second activity. In this activity, there are 100 spaces of the parking area, the number of 100 parking areas were used to direct the students in learning percent, where a percent is a number or ratio expressed as a fraction of 100 . For the details, here is the following the fourth conversation between the teacher and students in group 4 (S1 = the first student in the group, $\mathrm{S} 2$ = the second student, $\mathrm{S} 3$ = the third student, $\mathrm{G}=$ teacher) as follows:

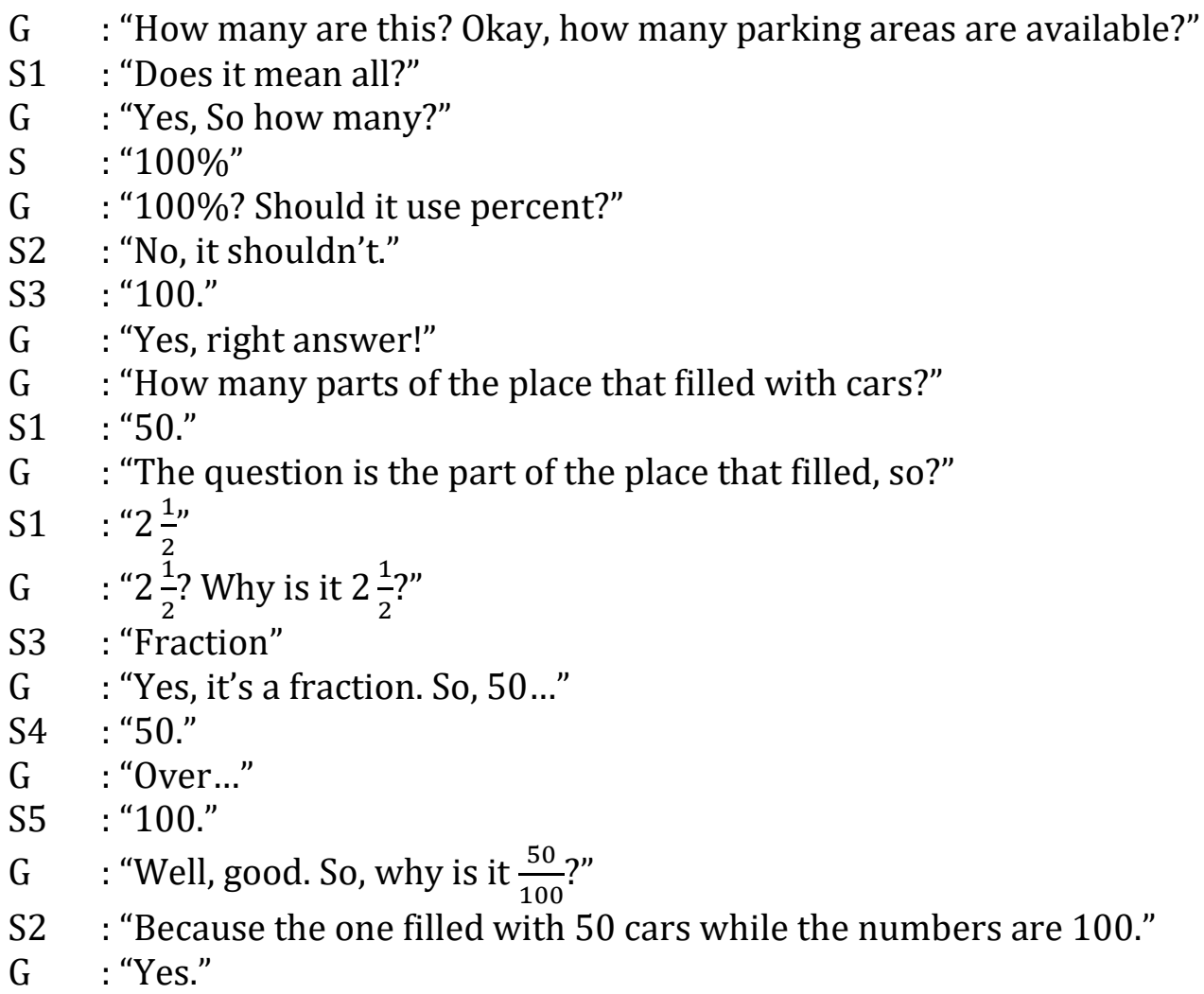


S3 : “Oh.. I see."

S1 : "That's what I mean mam."

Based on the discussion in the second activity, students already know the percent sign, then students were asked where do they find the sign of percent, and some students answered at the mall and when they checked their battery of the mobile phone. From the fourth conversations, it can be seen that students have been able to understand what was the question asked as well as students can solve the problem by modeling it into the bar percent, so it makes them easier to continue the formal mathematical. It shows that students can make a model by themselves or selfdeveloped models. Also, there is students' contribution when solving the problems and interactivity among students during the discussion process.

After that, the students discuss in their group to solve the problem given on students activities in the third activity. In the third activity, the teacher directs the percent material by linking the parking area with the bar, so the parking area divided into the percent. The conversation between the teacher and the students is as follows ( $\mathrm{S} 1$ = students in the group, $\mathrm{G}=$ teacher):

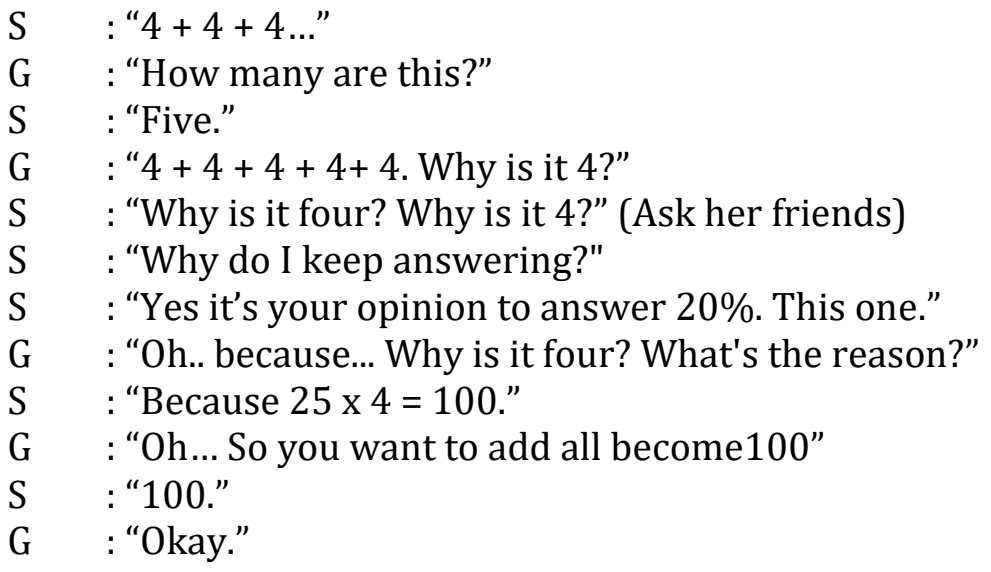

Based on the discussion process, the teacher can direct students to answer all questions in the sheet. Her, the teacher's role here is a guide for students so they can solve the problems by their knowledge. There is a PMRI principle that is called guided reinvention and has involved student contributions in completing it, and there are interactions between students and teachers in completing it (Zulkardi, 2002).

From the work of students, in activity 1 and individual questions, all students can solve correctly. Meanwhile, in activity 2, there is one problem from each group is still a constraint of low-ability students. But through collaborative learning, students who are less able to solve jumping questions by asking help the smart friend. According to (Putri, 2011), in PMRI learning, the use of contextual problem that contains mathematical concepts in daily life. Besides, during the learning process, the teacher uses students' worksheet that is designed using PMRI characteristics.

The learning carried out it is following the principles of PMRI, where students are guided to discover the percent concept through activities with the context of dart games designed, then using the phenomenon of educating and self-developed models (Zulkardi, 2002; Putri \& Zulkardi, 2018; Rahayu \& Putri, 2018).

After completing 2 activities, 30 students answered correctly, and only five students answered wrongly, meaning that there was a role of learning to use the

IJEME, Vol. 3, No. 1, March 2019, 105-116. 
context of filling the water in the measuring glass. After students understand the percent concept using a bar model, the teacher gave a jumping task to the students. Figure 7 shows the prediction of the teacher to the student solution.
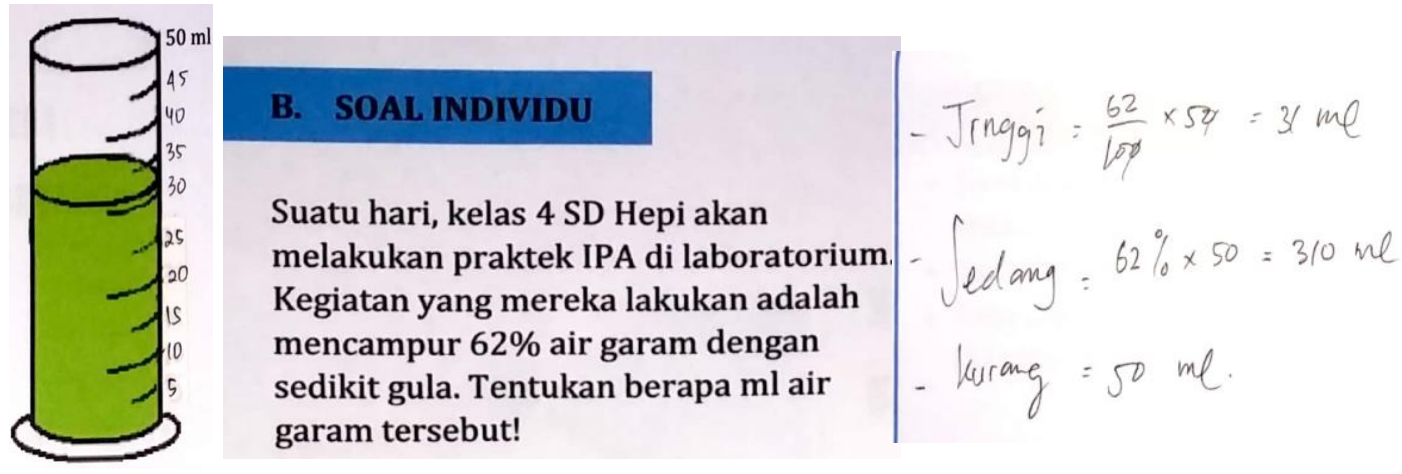

Figure 7. Teacher's prediction

During doing mathematics jumping task, students are working collaboratively in their groups. Students with low performance were guided and connected to ask questions to their peers with high perfomer. Figures 7 and 8 show the different of teacher prediction with the real student solutions. Teacher predicted that students with high performance only who can solve the problems, yet the middle students are also can do it. Even, the low performance can also try to do the problem although they still have a mistake. Hence, these results show that they have already learned in their groups (Sato, 2014).

$$
\begin{array}{ll}
62=\frac{62}{100} \times 5 \phi= & \frac{310}{10}= \\
6210=\frac{62}{200} \times 50 \mathrm{ml}=\frac{62}{2}=31 \mathrm{~mL} \quad \text { Low performance } \\
62 \%=\frac{62}{100} \times 50 \mathrm{ml}=\frac{62}{2}=31 \mathrm{ml} \quad \text { Hedium performance }
\end{array}
$$

Figure 8. Student's solutions

\section{CONCLUSION}

This research has produced a jumping task on mathematics at the topic of a percent which valid and practical with PMRI instructional theory and LSLC system in supporting students learning mathematics concept. Students have facilitated in understanding the percent concept through collaborative learning that connects students using the "Please Teach Me" rule. It is helpful and constructive for students who are low or moderate in understanding the concept of that need higher level order 
thinking skill. The results show that students with high performance can solve the jumping task, while students with low achievement have a problem in solving the jumping task. Yet, through collaborative learning, students with problems with percent concepts, finally, can resolve the HOTS jumping task.

\section{REFERENCES}

Gravemeijer, K., \& Cobb, P. (2006). Design research from the learning design perspective. In Van den Akker, J., Gravemerijer, K., McKenney, S., \& Nieveen, N. (Eds.), Educational Design Research. London: Routledge.

Gunawan, M.S., Putri, R.I.I., \& Zulkardi. (2017). Learning fractions through swimming context for elementary school students. Proceedings of 5th SEA-DR (South East Asia Development Research) International Conference 2017. Paris: Atlantis Press.

Indriasih, A. (2015). Pemanfaatan alat permainan edukatif ular tangga dalam pernerapan pembelajaran tematik di kelas III SD. Jurnal Pendidikan, 16(2), 127137.

Nizar, H., Putri, R.I.I., \& Zulkardi. (2018). Developing PISA-like mathematics problem using the 2018 Asian Games football and table tennis context.Journal on Mathematics Education, 9(2), 183-194.

Nofrion. (2012). Peningkatan aktivitas belajar siswa melalui penerapan metode "jumping task" pada pembelajaran geografi. Jurnal Geografi, 9(1), 11-30.

Parker, M., \& Leinhardt, G. (1995). Percent: A privileged proportion. Review of Educational Research, 65(4), 421-481.

Putri, R.I. (2011). Professional development of mathematics primary school teacher in Indonesia using Lesson Study and Realistic Mathematics Education approach. Proceeding of International Congress for School Effectiveness and Improvement (ICSEI). Cyprus: Lymasol.

Putri, R.I.I., \& Zulkardi. (2018). Noticing students thinking and quality of interactivity during mathematics learning. Proceedings of First Indonesian Communication Forum of Teacher Training and Education Faculty Leaders International Conference on Education 2017 (ICE 2017). Paris: Atlantis Press.

Putri, R.I.I., \& Zulkardi. (2017). Fraction in shot-put: A learning trajectory. AIP Conference Proceedings, 1868(1), 050005.

Putri, R.I.I. (2018). Soal HOTS dalam jumping task. Prosiding Seminar Nasional dan Workshop Matematika dan pendidikan Matematika. Padang: STKIP PGRI Sumatera Barat.

Rahayu, A.P., \& Putri, R.I.I. (2018). Learning process of decimals through the base ten strips at the fifth grade. International Journal of Instruction, 11(3), 153-162.

Rianasari, V.F., Budaya, I.K., \& Patahuddin, S.M. (2012). Supporting students' understanding of percentage. Journal on Mathematics Education, 3(1), 29-40.

Sato, M. (2014). Reformasi Sekolah Konsep dan Praktek Komunitas Belajar. Jakarta: Pelita.

Sato, M., \& Sato, M. (2003). Kodomo to Kyoshitsuno Jijitsu Kara Manabu [Learning Based on the Fact of Student and Classroom]. Tokyo: Gyosei. 
Van de Walle, J., \& Folk, S. (2005). Elementary and Middle School Mathematics: Teaching Developmentally. Toronto: Pearson Education Canada Inc.

Van de Walle, J. (2008). Matematika Sekolah Dasar dan Menengah. Jakarta: PT. Erlangga.

Van den Heuvel-Panhuizen, M. (1994). Improvement of (didactical) assessment by improvement of the problems: An attempt with respect to percentage. Educational Studies in Mathematics, 27(4), 341-372.

Van den Heuvel-Panhuizen, M. (2003). The didactical use of models in realistic mathematics education: An example from a longitudinal trajectory on percentage. Educational Studies in Mathematics, 54(1), 9-35.

Van Galen, F., \& Van Eerde, D. (2013). Solving problem with the percentage bar. Journal on Mathematics Education, 4(1), 1-8.

Van Galen, F., Feijs, E., Figueiredo, N., Gravemeijer, K., van Herpen, E., \& Keijzer, R. (2008). Fractions, Percentages, Decimals, and Proportions: A Learning-Teaching Trajectory for Grade 4, 5, and 6. Rotterdam: Sense Publishers.

Widiadi, A.N., \& Utami, I.W.P. (2016). A model of microteaching lesson study implementation in the prospective history teacher education. Journal of Education and Practice, 7(27), 10-14.

Zulkardi. (2002). Developing A Learning Environment on Realistic Mathematics Education for Indonesian Student Teacher. Doctoral Dissertation. Enschede: University of Twente. 
